\title{
Environmental Impact Assessment of Road Asphalt Pavements
}

\author{
Laura Moretti ${ }^{1}$, Paola Di Mascio ${ }^{1} \&$ Antonio D’Andrea ${ }^{1}$ \\ ${ }^{1}$ Department of Civil, Constructional and Environmental Engineeering, Sapienza, Università di Roma, Rome, \\ Italy \\ Correspondence: Laura Moretti, Department of Civil, Constructional and Environmental Engineeering, Sapienza, \\ Università di Roma, Rome, Italy. Tel: 39-6-4458-5124. E-mail: laura.moretti@uniroma1.it
}

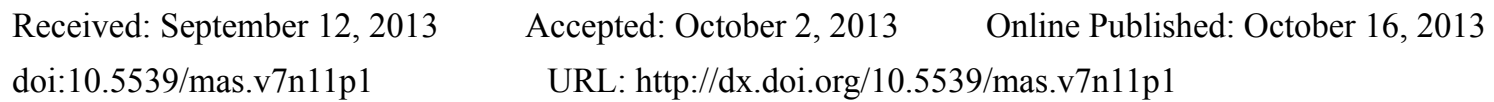

\begin{abstract}
This paper deals with a versatile, synthetic, simple and user-friendly method based on Life Cycle Assessment studies which summarizes multifaceted, often competing, environmental, technical and economic aspects in road construction. In many cases just economic criteria are applied in call for tenders, because the calculation of the environmental impact of road construction is difficult. In fact, it can be referred to many available options and both the economic and the environmental suitabilities have to be considered, in order to achieve globally sustainable results about road infrastructure work. In this research, the weighted sum model of multicriteria analysis is identified as the tool to evaluate global impact of road works, to compare solutions and to choose the best one.

The advantages of the proposed approach are that the local contest and the stakeholders' objective are represented by adopting variable parameters and weights, in order to apply the method to several contexts.

A case study explains potential environmental implications of using this new Road Environmental Impact Assessment to calculate effect related to the production of asphalt pavement, considering the production system for aggregates from cradle to gate, the materials transportation to road site and the works to have the road done.
\end{abstract}

Keywords: environment, road pavements, sustainability, green public procurement, multi criteria analysis

\section{Introduction}

\subsection{Pavement Surface and Road Performances}

Environmental evaluation of road infrastructure is as important as its technical and structural design. Not only economic criteria but also environmental criteria should be introduced in calls for tenders for the design/construction/maintenance of road infrastructure. Considering only economic costs, and often only construction costs, to evaluate a road project exposes society to unacceptable risk of improper decisions. In road works, design and construction decisions affect environmental impact during construction, all service life and demolition, which not only entail the current availability but also the future needs of resources and materials.

Also road calls for tenders may meet the demand of sustainability internationally recognized since 1987, when the first report published by The World Commission on Environment, "Our Common Future" points attention to sustainable development. This is "development that meets the needs of the present without compromising the ability of future generations to meet their own needs" (United Nations World Commission on Environment and Development, 1987). In 1996, the World Bank Group highlighted "the need to reform transport policy in order to support a better quality of life on a sustained basis". Particularly, "environmental and ecological sustainability requires that the external effects of transport be taken into account fully when public or private decisions are made that determine future development" (World Bank, 1996).

\subsection{Road Infrastructures and Sustainability}

As far back as 1996 issues of environmental problems appeared in document released by the European Commission. Communication COM(96)583 "Public Procurement in the European Union: Exploring the Way Forward Green Paper" presents the possibility for adopting "green" policy in public procurement, with enormous impact on related activities (European Commission, 1996). Public procurement policy may "generate sustainable, long term growth" and contribute to a better achievement of social and environmental policy objectives. In this Communication, European Commission enshrines that the environment protection policy is one of the most 
important Community policies and it should be an objective in the technical requirements relating to the characteristics of the works, supplies or services covered by a contract. The European Union acknowledges Public Administrations (PA) and authorities as consumers, which spend approximately 2 trillion euros annually, so they represents around 17\% of GDP in the EU. By promoting and using Green Public Procurement (GPP), public administrations can contribute to sustainable development and incentive studies and research for green technologies and products.

In 2009, the European Union Road Federation (ERF), the Brussels Programme Centre of International Road Federation (IRF), defines roads as sustainable if "through effective planning, design, construction, operation, maintenance and rehabilitation, they have the capacity to ... respect the environment". For ERF-IRF one of the environmental goals to sustainable roads is "developing a methodology to audit the environmental quality of road projects during their complete life cycle, from planning to maintenance, including not only planning materials, construction, maintenance, service and demolition, but also evaluation of the optimisation of the energy consumption of vehicles" (European Road Federation and International Road Federation Brussels Programme Centre, 2009). There is clear responsibility of the transportation sector in achieving the goals of sustainable development. Environment road work analysis can contribute to finding the most environmental advantageous solution), also considering the functional performances of road pavements (Loprencipe \& Cantisani, 2013). As yet, no one method has been defined to assess environmental impact of road construction work and compare solutions. Some software programs are available (PRé Consultants, 2007; Weidema et al., 2011) to calculate several types of environmental impacts, as greenhouse gases, land use, water and air pollution and water consumption. Methodology adopted by these software programs permits weighted analysis to choice between competing options.

This paper deals with an innovative methodology approach which is based on the multicriteria analysis (MCA). Each material, process or work needed to have the final product "road" affects the global environmental impact of construction or maintenance work. The proposed model takes into account all ecoinvents related to each single process. Each related dataset represents the production or transportation of 1 unit considering emission, raw materials and energy consumption. The proposed approach can be applied at all levels of decision-making to reduce deterioration and environmental impact, but also minimize costs and protect public health and social interests.

\section{State of the Art in Europe: Legal Framework}

In the previous years various documents adopted by European Commission witness the interest to apply environmental rules in public procurement. The following is a summary of the European legal framework about green public procurement. In 1997, the Single European Act in article 130r(2.2) states: "Environmental protection requirements shall be a component of the Community's other policies" (European Union, 1986).

The orientation of the Community legislature has strengthened in direction defined by the Green Paper (European Commission, 1996), through the new ideas identified in the Communication COM(2001)264 "Development Sustainable Europe for a Better World: A European Union Strategy for Sustainable Development". This Communication, presented during a European Council meeting in Gothenburg, emphasizes that Member States should make use of public procurement to promote products and services compatible with the environment (European Commission, 2001a).

Other European strategic documents which address this issue are the Communication COM(2001)274 "Interpretative Communication on the Community Law Applicable to Public Procurement and the Possibilities for Integrating Environmental Considerations into Public Procurement" (European Commission, 2001b), and the Communication $\operatorname{COM}(2001) 31$ "Sixth Environmental Action Programme: Environment 2010: Our future, Our Choice" (European Commission, 2001c). The first one acknowledges the "possibilities of the existing Community legal framework with regard to the integration of environmental considerations into public procurement". The second one highlights that public sector procurement can develop a market that includes environmental protection requirements. GPP is therefore a strategic tool also for the implementation of the Integrated Product Policy (IPP) launched by the "Green Paper on Integrated Product Policy" (European Commission, 2001d). The Commission Communication "Integrated Product Policy - Building on the concept of life cycle" confirms this rule and expressly provides the need for Member States to draw up National Action Plans for greening their public procurement (European Commission, 2001e).

In 2004, the adoption of the two European Directives on public procurement demonstrates how the Community legislature interest to promote sustainable development through the procurement legislation. The Directive 2004/17/EC of the European Parliament and of the Council of 31 March 2004 "coordinating the procurement 
procedures of entities operating in the water, energy, transport and postal services sectors" (European Parliament and Council, 2004a) and the Directive 2004/18/EC of the European Parliament and of the Council of 31 March 2004 "on the coordination of procedures for the award of public works contracts" (European Parliament and Council, 2004b) have outlined the framework for so-called "green procurement" of public administrations. Contracting authorities should pursue the protection of the environment and the promotion of sustainable development establishing environmental requirements in tenders. Directives introduce specific requirements to the adoption of environmental criteria in the selection of technical specifications and define award criteria contracts, services and supplies by public tender, applying the GPP within specifications.

The Directives accept the guidelines contained in the above-mentioned documents and acts, consistent with the provisions as referred to in Article 6 of Consolidated version of the Treaty On European Union (97/C 340/02) which states "Environmental protection requirements must be integrated into the definition and implementation of the Community policies and activities ...omissions..., in particular with a view to promoting sustainable development" (European Union, 1997).

The Communication "Public procurement for a better environment" (European Commission, 2008) defines Green Public Procurement as "a process whereby public authorities seek to procure goods, services and works with a reduced environmental impact throughout their life cycle when compared to goods, services and works with the same primary function that would otherwise be procured".

The Treaty of Lisbon, which entered into force on 1 December 2009, marked by incorporating the provisions of the Treaty on European Union (TEU), the first step towards the development of the concept of sustainable development into the common policies and within the Member States (European Union, 2007). So reads, in fact, the existing paragraph 3 of art. 3 of the TEU: "The Union shall establish an internal market. It shall work for the sustainable development of Europe based on balanced economic growth and price stability, a highly competitive social market economy, aiming at full employment and social progress, and a high level of protection and improvement of environmental quality. It shall promote scientific and technological progress" (European Union, 2010a). The art.11 of the Treaty on the Functioning of the European Union keeps the meaning of article 6 Treaty establishing the European Community and states: "Environmental protection requirements must be integrated into the definition and implementation of the Union policies and activities, in particular with a view to promoting sustainable development" (European Union, 2010b).

The latest stage of this path is made by the Communication from the Commission "Europe 2020: a strategy for a smart, sustainable and inclusive growth" which, in future scenarios for the Union, identifies the main line of evolution in smart, sustainable and inclusive where "growth sustainable means building an efficient in terms of resources, sustainable and competitive economy, exploiting Europe's leadership to develop new processes and technologies, including green technologies." In this way it aims to promote "the EU to prosper in a world of low-carbon and resource-constrained, while preventing environmental degradation, biodiversity loss and unsustainable use of resources and economic cohesion, social and territorial cohesion" (European Commission, 2010a).

The Communication "Green paper on the modernisation of EU public procurement policy towards a more efficient European Procurement Market" identifies the areas that could be subject to changes and adjustments to existing EU legislation (European Commission, 2011). The Commission has launched a finished public consultation on paper, so the Commission probably will present specific legislative proposals to simplify and update the existing regulatory framework for public procurement set by Directives 2004/17/CE and 2004/18/EC.

\section{Green Public Procurement in Europe}

The EU Commission has now published recommendations to define GPP criteria for nineteen sectors. These products or services have common EU GPP criteria:

- copying and graphic paper;

- cleaning products and services;

- office IT equipment;

- construction;

- transport;

- furniture;

- electricity; 
- food and Catering services;

- textiles;

- gardening products and services;

- windows;

- thermal insulation;

- hard floor-coverings;

- wall Panels;

- combine Heat and Power;

- $\quad$ road construction and traffic signs;

- street lighting and traffic signals;

- mobile phones;

- indoor lighting.

Member States and European local authorities have started to integrate environmental considerations into their public procurement, however the green tenders successfully launched so far do not concern road infrastructures.

Green public procurement has been highlighted as an important element in the Sustainable Energy Action Plan (SEAP) guidebook, which stipulates that the plans should cover areas "where local authorities can encourage markets for energy efficient products and services" (Bertoldi et al., 2010).

The biggest obstacles to GPP dissemination are:

- poor flexibility of public organizational structures, cultural inertia, elements of misinformation and disinformation;

- lack of awareness of environmental issues by the producers;

- lack of knowledge of the GPP approach and lack of information on green products;

- difficulty to define and recognize the characteristics of "green" products or services;

- technical and organizational difficulties during management of green tenders (main obstacle in $85 \%$ of cases);

- perception of green products as more expensive than conventional (53\%);

- difficulty in finding suppliers of green products or services (33\%).

- Austria, Denmark, Finland, Germany, The Netherlands, Sweden and the United Kingdom are the seven best performing EU Member States in terms of GPP.

In 2008, a study developed calculating methods to measure GPP requirement (PriceWaterhouseCoopers, Significant and Ecofys, 2009). Two indicators have been defined:

- the \% GPP of total public procurement, in terms of monetary value (as a);

- the \% GPP of total public procurement, in terms of the number of contracts (as b).

Taking account the ten product groups identified by European Community (European Commission, 2008). as most suitable for greening under Green Public Procurement, average value of indicator a is more than $30 \%$, equally distributed between core and comprehensive green. "Comprehensive" is the best environmental product available on the market, which may require additional administrative effort or implies a certain cost increase as compared to other products fulfilling the same function. "Core" is the most significant environmental impact with minimum additional verification effort or cost increases.

The introduction of environmental criteria is a relatively current practice because it requires special policies by the government agencies and green procurement has economic impact not yet considered by the PA. It will be possible to obtain higher levels of environmental compatibility both in requirement and in achievement only after having a critical and constructive sustainability approach at all steps.

Against traditional goods or services, green purchases may have higher economic costs, but ensures lower environmental impact. Estimated total average economic and environmental costs show the global advantage of a green solution. Only a critical and global approach can lead to correct evaluation of environmental impact.

For example, many would uncritically assign a positive value to the purchase of recycled aggregates. There are 
legislative choices in this regard (Italian Ministry of the Environment, 2003; Italian Ministry of the Environment, 2005) Aggregates with equivalent performance requirements (D'Andrea et al., 2004) can be bought by taking a natural aggregate from a nearby quarry, or from a faraway plant of recycled granulate which requires more attention. Comparative Life Cycle Analysis (LCA) between these two cradle to gate materials is advantageous for the latter. The global LCA, including transport and laying, comes out the side of the former. However, introducing the LCA and the social value assigned to the collection from quarry and the reduced use of landfill, may be preferable the latter. During design phase, environmental criteria cannot simply refer to the environmental performance of materials and/or construction products but must make a "green" project case by case.

As referred in the "Road Construction and Traffic Signs Technical Background Report", the Belgian Road Research Centre points out that whilst cold asphalt might save energy and therefore cost of production as opposed to conventional hot asphalt, it has the trade off in that it has to be replaced more frequently, thus incurring maintenance and capital costs (D'Andrea \& Fiore, 2003). So, if more options are available, comparative LCA should be taken to ensure the environmentally preferable solution. The proposed methodology aims to avoid the risk of judging "the greenest" environmental product that has less environmental impact performance of materials.

At present, both the efforts of the European Commission and the international community (ISO 14001: 2004, ISO 14004: 2004) to preserve the Earth and its resources did not affect decision concerning the design, construction, maintenance, rehabilitation of road infrastructures. Probably, the experience gained in the fields of industry, energy, food and service will lead to apply GPP also in the field of road materials.

\section{Methodology to Apply GPP in Road Construction}

The approach to fatigue design instead of maximum permissible load and the visible early evolution of a road to its "destruction" (progressive deterioration of structural and functional level of service between two subsequent maintenance or reconstruction works) are specific characteristics of roads (European Commission, 2010b). In road construction and maintenance, it is also necessary to distinguish, for environmental purposes, the operation phase from the construction/maintenance one. The environmental consequences of the operation phase are poorly mitigated by constraints imposed by functional choices, needs for safety and traffic flow and constraints mapping. Just modifications to the vehicles and not different composition of the tracks or contributions of new materials can significantly reduce the environmental impact of the road during its life service (Cantisani, Loprencipe, \& Primieri, 2011).

Therefore, once established geometric design, it needs to build and maintain the road. These activities have specific significant influence on the environmental impact (Moretti, 2012).

Although the environmental harm caused by the construction and maintenance is far less than the harm resulting from the traffic, it is only on the work that public administrations can effectively apply the green purchasing policy. Green road Procurement is often reduced defining the minimum environmental criteria for each supply required for construction and maintenance, as aggregates, binder, additives. Misinterpreting the concept of "green procurement", the road design process may run into false interpretations of the spirit of the European Directives.

What studies about product costs attributed to the user, like "Life Cycle Cost" (LCC), and about environmental impact of a product from cradle to grave, like LCA, so far have highlighted the difficulty of achieving acceptable overall results. Evaluations are conducted in the absence of unique methodologies that summarize in economic terms the multifaceted social and economic aspects. In the light of the mentioned outcomes, the present research was carried out to better take account of sustainable aspects in the procurement processes (Di Mascio et al., 2012). The method adopted for the new approach to strategic environmental assessment of road projects is based on final dimensionless synthesis of environmental consequences related to each material or workmanship road. Chemical or physical indicators are evaluated and summed according to their own units of measurement without the need to monetize the environmental impact and so establish the cost of each. Including environmental criteria in road design, construction and maintenance allows a trend towards the objective of the Green Road. Environmental criteria are used to optimize the efficiency of use of resources and the reduction of direct and indirect environmental impact. A primary operational tool for assessing road environmental performance could be the "Environmental Bill of Quantities", modelled after the Bill of Quantities. This has a modular structure and consists of chapters on item of environmental harm related to each material or work. So, it's possible to obtain an objective assessment of single components involved in the environmental report. For example, the Environmental Bill of Quantities takes into account: 
- emission of greenhouse gases,

- water consumption,

- use of raw materials and secondary raw materials,

- production of waste including hazardous waste,

- energy consumption recorded in all processes related to the finished product "road",

- issue of gases that destroy the ozone layer,

- acidification, photochemical oxidant formation,

- powder emissions.

Where available, each entry of environmental pollution appears in each product sheet of materials, machines and operations.

Product data sheets, provided by the manufacturers and certified according to ISO 14025 (ISO 14025:2006), should be like EPD ${ }^{\circledR}$. EPD is an environmental declaration developed in Sweden to provide environmental information and become an international reference. An environmental Bill of Quantities can be complementary to the Bill of Quantities and can help to compare products that fulfill the same function. Research has identified the MCA as a tool to support the decision-making (Dano et al., 2011) as an appropriate means for assessing a road project with a GPP approach. The MCA method results in an overall satisfactory solution about parameters of environmental priority established by the PA. The comparison algorithm permits for the evaluation projects according to varying criteria, selected and weighted by the PA. Depending on the specific configuration of the problem, a selected risk-seeking pool chooses the weighting factors between zero and one (Lazim et al., 2013). In fact, the impact of the same environmental parameter varies with the local contest and the stakeholders' objective (Abdullahi et al., 2013).

\section{Case Study}

The authors estimated environmental impact of $1 \mathrm{~m}^{3}$ of three asphalt concrete mixes to be applied in a road pavement. Bituminous binder compositions consist of volumetric quantities presented in Table 1.

Table 1. Products or services with EU GPP criteria

\begin{tabular}{ccccc}
\hline & \multicolumn{3}{c}{ Volumetric quantity } & Density \\
& Bitumen & Aggregates & Void content & $\mathrm{kg} / \mathrm{m}^{3}$ \\
\hline Mix1 & $11 \%$ & $84 \%$ & $5 \%$ & 2386 \\
Mix2 & $12 \%$ & $83 \%$ & $5 \%$ & 2363 \\
Mix3 & $12 \%$ & $83 \%$ & $5 \%$ & 2363 \\
\hline
\end{tabular}

In the Mixes 1 and 2:

- $80 \%$ of the coarse and fine aggregates is available in a quarry $30 \mathrm{~km}$ away from the asphalt concrete plant;

- $20 \%$ of the coarse and the fine aggregates and filler is in a quarry $55 \mathrm{~km}$ away from the asphalt concrete plant.

In the Mix 3 :

- $80 \%$ of the coarse and fine aggregates is available in a quarry $35 \mathrm{~km}$ away from the asphalt concrete plant;

- $20 \%$ of the coarse and the fine aggregates and filler is in a quarry $50 \mathrm{~km}$ away from the asphalt concrete plant.

The road construction site is $25 \mathrm{~km}$ away from the asphalt concrete plant.

Environmental impacts are derived by:

- for bitumen and emulsion bitumen, the Life Cycle Inventory of Bitumen published by Eurobitume in 2012 (Eurobitume, 2012); 
- for aggregates, the Environmental Impact Categories of cradle to gate aggregates defined by Union Européenne des Producteurs de Granulats (European Aggregates Association) in 2012 (Union Européenne des Producteurs de Granulats, 2012) and by Cimbéton in 2011 (CIMbéton, 2011);

- for transportation and operating machines manufacturers' data sheets, the Cimbéton's analysis and data published by Wirtgen (CIMbéton, 2011; Wirtgen, 2013).

The examined impact categories are: nonrenewable resources, renewable resources, electric energy, photochemical oxidant formation potential, hydric resources, nonhazardous waste, hazardous waste, equivalent carbon dioxide emission, ozone depleting substances emission, acidification, photochemical oxidation, eutrophication, powder emission and ecotoxicity.

Table 2 shows the quantity of materials and work need to produce, transport and pave $1 \mathrm{~m}^{3}$ of the mixes.

Table 2. Materials and working need to produce, transport and pave $1 \mathrm{~m}^{3}$ of asphalt concrete

\begin{tabular}{|c|c|c|c|c|}
\hline \multirow{2}{*}{ Material } & \multirow{2}{*}{ Unit } & \multicolumn{3}{|c|}{ Quantity } \\
\hline & & Mix1 & Mix2 & Mix3 \\
\hline Bitumen & $\mathrm{kg}$ & 108.22 & 122.4 & 122.4 \\
\hline Aggregates (cradle to gate) & $\mathrm{kg}$ & 2278.51 & 2241 & 2241 \\
\hline Transportation with $16 \mathrm{t}$ truck & $\mathrm{tkm}$ & 54.68 & 62.74 & 62.74 \\
\hline Transportation with $32 \mathrm{t}$ truck & tkm & 27.22 & 25.47 & 25.47 \\
\hline Working machines & $\mathrm{h}$ & 0.01 & 0.01 & 0.01 \\
\hline Track paver & $\mathrm{h}$ & 0.01 & 0.01 & 0.01 \\
\hline Pneumatic roller $18 \mathrm{t}$ & $\mathrm{h}$ & 0.01 & 0.01 & 0.01 \\
\hline Tandem vibratory roller $8 \mathrm{t}$ & $\mathrm{h}$ & 0.01 & 0.01 & 0.01 \\
\hline Bitumen emulsion & $\mathrm{kg}$ & 14.29 & 14.29 & 14.29 \\
\hline Truck & $\mathrm{h}$ & 0.08 & 0.08 & 0.08 \\
\hline Spraying machine & $\mathrm{h}$ & 0.01 & 0.01 & 0.01 \\
\hline
\end{tabular}

These environmental factors depend on the specific geographical and environmental context in which works are conducted.

Table 3 shows the Environmental Bill of Quantities referred to all processes related to the finished product " $1 \mathrm{~m}^{3}$ of asphalt concrete". This tool allows to compare more asphalt concrete mixes.

Each list of impact category quantities is the vector $d$ which represents environmental impact related to its mix. Stakeholder may compare the presented mixes using weighted sum model of multicriteria analysis.

To compare $\mathrm{m}$ design alternatives, vector $d\left(1^{*} n\right)$ must be created for each design alternative. The vector lists total impact in each of $n$ examined environmental categories. All vectors $d$ for all $m$ alternatives may be represented in the matrix of alternatives $(A)$, see Equation (1), that may be used in the multi-criteria decision method of weighted sum model.

$$
A=\left[\begin{array}{lll}
a_{1,1} & \cdots & a_{1, n} \\
\cdots & \cdots & \cdots \\
a_{i, 1} & a_{i, j} & a_{i, n} \\
\cdots & \cdots & \cdots \\
a_{m, 1} & \cdots & a_{m, n}
\end{array}\right]
$$


Table 3. Environmental bill of quantities of $1 \mathrm{~m}^{3}$ of asphalt concrete

\begin{tabular}{lcccc}
\hline Impact category & Unit & \multicolumn{3}{c}{ Quantity } \\
\hline Nonrenewable resources & & Mix1 & Mix2 & Mix3 \\
Renewable resources & $\mathrm{MJ}$ & 741 & 804 & 815 \\
Nonrenewable resources & $\mathrm{MJ}$ & 0 & 0 & 0 \\
Renewable resources & $\mathrm{kg}$ & 2387 & 2363 & 2363 \\
Electric Energy & $\mathrm{kg}$ & 0 & 0 & 0 \\
Photochemical Oxidant Formation Potential & $\mathrm{kWh}$ & 27 & 26 & 26 \\
Hydric resources & $\mathrm{kg}$ & 0.58 & 0.66 & 0.66 \\
Nonhazardous waste & 1 & 731 & 726 & 726 \\
Hazardous waste & $\mathrm{kg}$ & 558 & 549 & 549 \\
Equivalent carbon dioxide emission & $\mathrm{kg}$ & 0 & 0 & 0 \\
Ozone depleting substances emission & $\mathrm{kg} \mathrm{CO}_{2}$ eq & 58.9 & 62.3 & 63.1 \\
Acidification & $\mathrm{kg} \mathrm{CFC}^{-11}$ eq E-08 & 0 & 0 & 0 \\
Photochemical oxidation & $\mathrm{kg} \mathrm{SO}_{2}$ eq & $6.6 \mathrm{E}-1$ & $7.3 \mathrm{E}-1$ & $7.3 \mathrm{E}-1$ \\
Eutrophication & $\mathrm{kg} \mathrm{C}_{2} \mathrm{H}_{4}$ eq & $8.0 \mathrm{E}-2$ & $7.8 \mathrm{E}-2$ & $7.8 \mathrm{E}-2$ \\
Powder emission & $\mathrm{kg} \mathrm{PO}_{4}{ }^{-3}$ eq & $8.0 \mathrm{E}-1$ & $9.0 \mathrm{E}-1$ & $9.0 \mathrm{E}-1$ \\
Ecotoxicity & $\mathrm{kg}^{2}$ & $1.3 \mathrm{E}-4$ & $1.2 \mathrm{E}-4$ & $1.2 \mathrm{E}-4$ \\
\hline
\end{tabular}

A physical dimension is associated to each element $\mathrm{a}_{\mathrm{i}, \mathrm{j}}$ of $A$ matrix, so must be calculated the dimensionless decision matrix $(D)$ using for each of $n$ environmental categories the functions as Equation (2):

$$
f(j)=[0,1]
$$

that vary according to the project and depend on range:

$$
\max \left(a_{i, j}\right)-\min \left(a_{i, j}\right) .
$$

Knowing $f(j)$, the elements $\mathrm{d}_{\mathrm{i}, \mathrm{j}}$ are calculated in Equation (3):

$$
D=\left[\begin{array}{lll}
d_{1,1} & \cdots & d_{1, n} \\
\cdots & \cdots & \cdots \\
d_{i, 1} & d_{i, j} & d_{i, n} \\
\cdots & \cdots & \cdots \\
d_{m, 1} & \cdots & d_{m, n}
\end{array}\right]
$$

Product between the $m^{*} n$ dimensionless decision matrix $(D)$ and the column $n^{*} l$ weight vector $(w)$ allows to calculate the impact vector $i$ by Equation (4).

$$
D \times w=i
$$

Each weight represents the different cultural perspectives (Frischknecht \& Hofstetter, 1996) with which environmental problems and uncertainties related to them are perceived.

Each element $\mathrm{i}_{\mathrm{i}, \mathrm{m}}$ of $i$ vector represents in a concise and numerical way the environmental impact of $\mathrm{i}$-th design alternative.

Appling Equation (4), having the weight vector $w$ represented in Equation (5)

$$
w=(0.3 ; 0.12 ; 0.02 ; 0.02 ; 0.07 ; 0 ; 0 ; 0.01 ; 0.01 ; 0.02 ; 0.2 ; 0 ; 0.2 ; 0.02 ; 0.01 ; 0)
$$

The Mix 2 has the lowest environmental impact, equal to 0.35 (Table 4). 
Table 4. Environmental bill of quantities of $1 \mathrm{~m}^{3}$ of asphalt concrete

\begin{tabular}{lccc}
\hline & Mix1 & Mix2 & Mix3 \\
\hline Environmental impact & 0.36 & 0.35 & 0.49 \\
\hline
\end{tabular}

The presented case study demonstrates that the proposed method allows the numeric comparison between synthetic dimensionless variables using weights defined by the PA on local environmental context. MCA can be applied at all levels of decision-making, from the consideration of project alternatives to road-reaching policy decisions guiding a transition towards sustainability and the green economy. The new approach may be applied to evaluate global sustainability of examined problem, including social and economic factors. Road infrastructure works are expensive and often cause congestion, so their global impact affects global sustainability.

Moreover, MCA applied to GPP in road work may boost competitiveness in this sector, enhancing construction industry practices to raise the productivity, quality and timeless of transport infrastructure projects.

\section{Conclusions}

Issues of Environmental Aspects in public administration (PA) management are often named in international institutional frameworks. There needs to be a tool for pursuing environmental policy objectives during road life service. The present paper suggests an innovative method developed by the Civil, Building and Environmental Department of Sapienza University of Rome to estimate environmental impact of works. The model is based on knowing the environmental consequences of each material or work related to road construction, maintenance or rehabilitation certificated by producers or service providers. Life cycle environmental analysis (LCEA) allows to quantify impact of each road project decision. Integrating the LCEA with the methodology of multi-criteria analysis can be achieved a summary and dimensionless environmental impact assessment. The new method is valid for objectively compare different solutions.

The new methodology enables identification and quantification of environmental impact of road materials and construction, so effects on the environment can be evaluated for each item of environmental bill of quantities, a modular structure related and complementary to the bill of quantities. The proposed procedure is a robust, transparent and forward-looking decision framework that assesses environmental impact of road works using a versatile and user-friendly tool. MCA is valuable and increasingly widely-used tool to aid decision-making when there are competing options, as in road infrastructure work. The current study has practical implications as well. In effect, the approach is modular and simple. It could be a valid tool for designers, planners, decision-makers, government agency personnel, proponents and consultants. The tool allows analysis of environmental impact of road works with a procedure analysis that compares alternatives considering various impacts, both environmental and economic and social, chosen by stakeholders. It provides a decision-making structure towards the sustainability, the green economy and political, economic and social trends.

\section{References}

Abdullahi, A. U., Noor Amila Wan, A. Z., Mohd, F. K., \& Arazi, I. (2013). Stakeholder Perceptions on Achieved Benefits of PFI Procurement Strategy. Modern Applied Science, 7(4), 31-40. http://dx.doi.org/10.5539/mas.v7n4p31

Bertoldi, P., Bornás Cayuela, D., Monni, S., \& Piers de Raveschoot, R. (2010). Guidebook: How to Develop a Sustainable Energy Action Plan (SEAP). Publications Office of the European Union, Luxembourg. http://www.eumayors.eu/IMG/pdf/seap_guidelines_en.pdf

Cantisani, G., Loprencipe, G., \& Primieri, F. (2011). The Integrated Design of Urban Road Intersections: A Case Study. ICSDC 2011, 426, 722-728. http://dx.doi.org/10.1061/41204(426)88

CIMbéton. (2011). Analyse du cycle de vie de structures routières-T89. Paris, France: Collection Technique CIMbéton.

D'Andrea, A., Bonora, V., \& Drago, D. (2004). Asphalt concrete with bottom ash: Environmental aspects. Proceedings of the International Conference of Restoration, Recycling and Rejuvenation Technology for Engineering and Architecture Application held in Cesena, Italy, June 7-11, pp. 56-63.

D'Andrea, A., \& Fiore, N. (2003). Fatigue life of asphalt concrete with rubber grains. Advances in Damage Mechanics, 65-74.

Dano, U. L., Abdul-Nasir, M., \& Abdul-Lateef, B. (2011). A Geographic Information System and Multi-Criteria 
Decision Analysis in Proposing New Recreational Park Sites in Universiti Teknologi Malaysia. Modern Applied Science, 5(3), 39-55.

Di Mascio, P., Moretti, L., \& Panunzi, F. (2012). Economic Sustainability of Concrete Pavements. Procedia-Social and Behavioral Sciences, 53(3), 125-133. http://dx.doi.org/10.1016/j.sbspro.2012.09.866

Eurobitume. (2012). Life Cycle Inventory of Bitumen. Brussels, Belgium: Published by the European Bitumen Association. Retrieved from http://www.eurobitume.eu/system/files/LCI_Bitumen_27072012.pdf

European Commission. (1996). Public Procurement in the European Union: Exploring the Way Forward. Green Paper. Communication COM(96)583.

European Commission. (2001a). Development Sustainable Europe for a Better World: A European Union Strategy for Sustainable Development. COM(2001)264.

European Commission. (2001b). Interpretative Communication on the Community Law Applicable to Public Procurement and the Possibilities for Integrating Environmental Considerations into Public Procurement. Commission Interpretative Communication. COM(2001)274.

European Commission. (2001c). Sixth Environmental Action Programme: Environment 2010: Our future, Our Choice. Communication from the Commission to the Council. COM(2001)31.

European Commission. (2001d). Green Paper on Integrated Product Policy. Communication. COM(2001)68.

European Commission. (2001e). Integrated Product Policy-Building on the concept of life cycle. Communication from the Commission to the Council and the European Parliament. COM(2003)302, 2003.

European Parliament and Council. (2004a). Directive 2004/17/EC of 31 March 2004 coordinating the procurement procedures of entities operating in the water, energy, transport and postal services sectors.

European Parliament and Council. (2004b). Directive 2004/18/EC on the coordination of procedures for the award of public works contracts.

European Commission. (2008). Public procurement for a better environment. Communication from the Commission to the European Parliament, the Council, the European Economic and Social Committee and the Committee of the Regions. COM(2008)400.

European Commission. (2010a). Europe 2020: a strategy for a smart, sustainable and inclusive growth. Communication from the Commission. $\operatorname{COM}(2010) 2020$.

European Commission. (2010b). Road Construction and Traffic Signs Technical Background Report. AEA, Harwell.

European Commission. (2011). Green paper on the modernisation of EU public procurement policy towards a more efficient European Procurement Market. COM(2011)15.

European Road Federation and International Road Federation Brussels Programme Centre. (2009). The Future of Transport: Strategic Road Infrastructure Priorities-Beyond 2010.

European Union. (1986). Single European Act.

European Union. (1997). Consolidated version of the Treaty On European Union. 97/C 340/02.

European Union. (2007). Treaty of Lisbon amending the Treaty on European Union and the Treaty establishing the European Community. Signed at Lisbon, 13 December 2007.

European Union. (2010a). Consolidated version of the Treaty on European Union.

European Union. (2010b). Consolidated version of the Treaty on the Functioning of the European Union.

Frischknecht, R., \& Hofstetter, P. (1996). Electricity and Transportation in Ecolabelling, Appendix 3 in Udo de Haes H. A., Clift, R., Griesshammer, R., Grisel, L., Jensen, A. A., et al. Practical Guidelines for Life Cycle assessment for the EU ecolabelling programme, Final report of the third phase, Leiden.

ISO 14001:2004. Environmental management systems-Requirements with guidance for use.

ISO 14004:2004. Environmental management systems-General guidelines on principles, systems and support techniques.

ISO 14025:2006. Environmental labels and declarations-Type III environmental declarations-Principles and procedures.

Italian Ministry of the Environment. (2003). Regulations to public offices and companies with a majority public 
capital to cover the annual needs of works of art and goods with a market share of products made from recycled materials to the extent of not less than 30\% of the same needs. Decree n.203/2003.

Italian Ministry of the Environment. (2005). Indications for operation in the construction industry, road and environment within the meaning of the Ministerial Decree of 8 May 2003, n. 203. Circular n. 5205/2005.

Lazim, A., Wan, K., \& Wan, I. (2013). A New Ranking of Environmental Performance Index Using Weighted Correlation Coefficient in Intuitionistic Fuzzy Sets: A Case of ASEAN Countries. Modern Applied Science, 7(6), 42-52. http://dx.doi.org/10.5539/mas.v7n6p42

Loprencipe, G., \& Cantisani, G. (2013). Unified Analysis of Road Pavement Profiles for Evaluation of Surface Characteristics. Modern Applied Science, 7(8), 1-14. http://dx.doi.org/10.5539/mas.v7n8p1

Moretti, L. (2012). Modello di analisi strutturale, funzionale ed economica di pavimentazioni stradali in calcestruzzo. PhD Thesis, Sapienza University of Rome, Italy.

$\begin{array}{lllllll}\text { PRé Consultants. } & \text { (2007). } & \text { SimaPro } & 7 & \text { Tutorial. } & \text { Retrieved } & \text { from }\end{array}$ http://www.stanford.edu/class/cee214/Readings/SimaPro7Tutorial.pdf

PriceWaterhouseCoopers, Significant and Ecofys. (2009). Collection of statistical information on Green Public Procurement in the EU-Reports on methodologies. Retrieved from $\mathrm{http} / / /$ cc.europa.eu/environment/gpp/pdf/statistical_information.pdf

Union Européenne des Producteurs de Granulats. (2012). Environmental Impact Categories of cradle to gate aggregates.

United Nations World Commission on Environment and Development. (1987). Report of the World Commission on Environment and Development: Our Common Future. Document transmitted to the General Assembly as an Annex to document A/42/427-Development and International Cooperation: Environment.

Weidema, B. P., Bauer, C., Hischier, R., Mutel, C., Nemecek, T., Vadenbo, C. O., \& Wernet, G. (2011). Overview and methodology: Data quality guideline for the ecoinvent database version 3. Retrieved from http://www.ecoinvent.org/fileadmin/documents/en/ecoinvent_v3_elements/01_DataQualityGuideline_Final Draft_rev1.pdf

Wirtgen. (2013). Technical specifications. Retrieved from http://www.wirtgen.de/en/

World Bank. (1996). Sustainable Transport: Priorities for Policy Reform. Washington, DC.

\section{Copyrights}

Copyright for this article is retained by the author(s), with first publication rights granted to the journal.

This is an open-access article distributed under the terms and conditions of the Creative Commons Attribution license (http://creativecommons.org/licenses/by/3.0/). 